ある。他のもう一つの型はカタル性症狀 (catarrhal type)非常なる慢性的萎繀的性質で上述のものと閍別

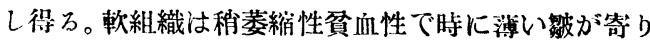

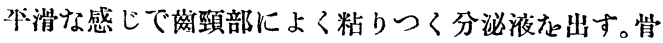
の椿造には多少の壞死狀態吉見せこの型と非毒性型 とは組織の性狀と多最の非常に埏一難い臭氣のむ万 分泌液た出すのて區別し得るのであると。

次いで本症の治潦に關する Dunlop 氏の功績たた >一更にダンロップ氏法の發達過程を以下の如く述べ

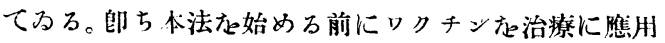

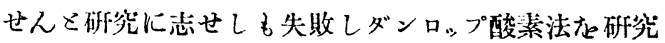
しホのの゙゙る。りクチンは體內に入ると體細胞亦刺激 して抗原體な作りその個體は免度な得るのであるが 之は特買的のものでむ万故に混合感染の場合はこの

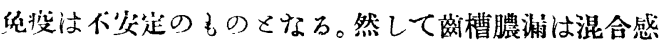
热でする故に是等のワクチン应得万のは開題でする。 ダンロップ氏法は篓體として酸素瓦斯な用ひその腐蝕 的作用交利用して細胞の同化作用に好都合に㗢かし める、噴蓩が組織上な通過すると之に沿ひ賀血性の椖 白走みる。この後數時間な經ると充分に充血が起り白 血球没潤も起る。之が藏凬全體に生成されて疾患に與 つてみ万微生:物注㨁接に白血球の體內に取り边まれ て破壇されろ。清素に解籍されて血行中に入り體細胞 に接触して感染志克服す万抗原體の出產在行子。之店

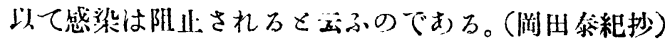

\section{補 緅}

機能的白齒

Lin Funktions-Backenzahn (Cavidens) von

Dr. Hans Joachin Freitag. Deutsche

Zahnärztliche Wochenschrift Nr. 33,

München, 16 August 1940)

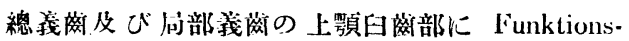
Backenzähne（Cavidens-zähne）打ひてるる。この

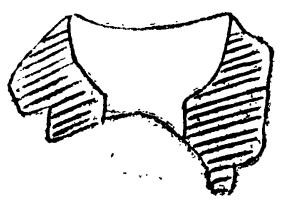

圖 1

Cavidens-zahn 沙合面を持たないで䧃 1 (側面より

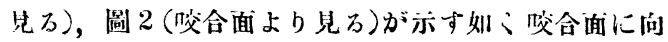

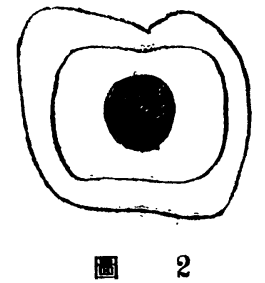

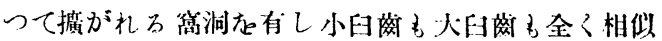

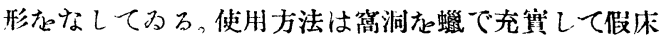

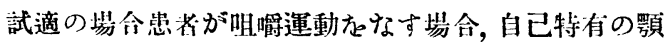

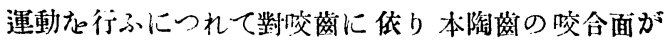
形成されるのである，その際强度の咬䫒や溝芷形成す 万事なく適度な万生理學的咬合面が作られろのであ 万。斯くの如くして得られたる咬合面に陶材模色彩の 義菻材料(白色ゴム)衣垻入寸る。この方法に依れば對

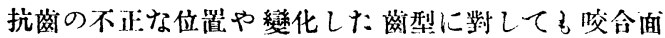
法理想的滑走接解が得られるを同特化完成特に非常 に良奵なる結果が得られる。

Cavidens-zähne の本筫的長所泣次の如 L

1) 䋓龂的证磪な憡合

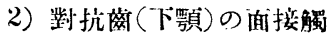

3）呮合機能に際して障碍される溝及び咬䫓な有し ない。

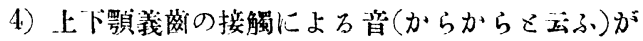

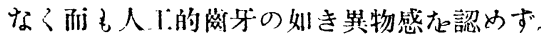

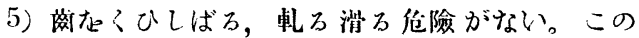
Cavidens-zähne 在使肋するには次の事柿が報告され てるら。

\section{總我幽の製作}

先つ上卜顠の前爷在既矨の法则により配列しHつ その際䫕運動により上下前前は相互障碍せられざる

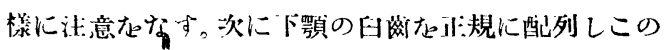

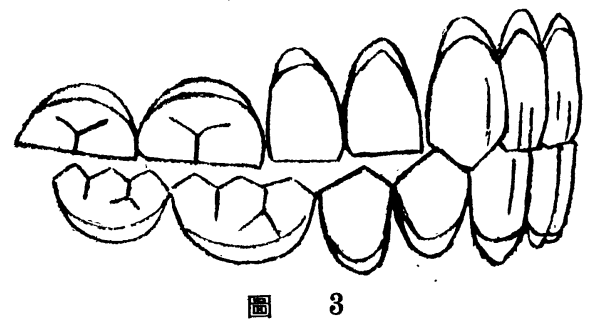

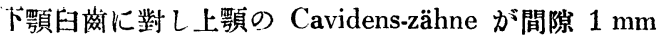
にな万ように配列し. (阔 3), 更に此の Cavidens-zähne

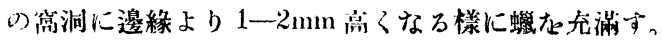



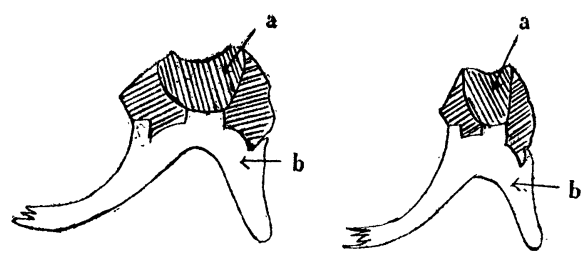

圆 4

次に咬合器を動かし，その Cavidenszähne 中に充た せろ蠟が偷軟化せる間に下顎茲牙咬合面を以て, 上顎 茼车咬合面の形成吕行子。餘分の蠟志除去した後フラ

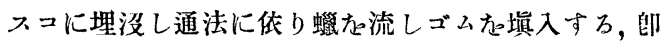
ち先づ Cavidenszähne の裳洞に陶材色ゴムた確賽に

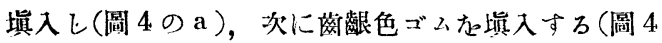

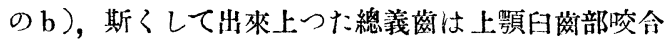
面は外界より殆ど見へないし，色澤 主陶材色 (白色) なれば外觀的にも異變なく且つ機能的には前述せる が如く極めて自然的に顎運動に 調和せる咬合局面が

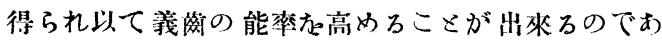
ろ。

(不用抄)

\section{矯 正科}

\section{矯正施術に依る齒牙延長}

Artificial Elongation of Teeth. by Oppenheim.

A. A. J. O., 1940, No 10, p. 931.

矯正施術に於け万落牙延長の際の組織變化。

人工的に巤牙の延長た行つけ際に起る, 組織變化に 就いては, 余の知れる範圍內に於いては，曾て余が猿 の落牙に就いて行つた, 矯正施術中に於け万組織變化 の報告以外には誰の報告も無い樣である。當時の余の 報告に於いては，蓄牙の延長方行つけ際，幽槽緣の兹 根膜織維な通じて, 刺战が兴槽緣項に傳わり，その結 果として繮槽緣頂が發育することな迅べた。

今回余は舌側弧線吉用いて前牙の延長走行ひ, 其際

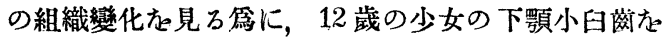
用ひて $1.5 \mathrm{~mm}$ の延長方行つた。倘該蓄牙は對合兹と 接解して居万雼， 2 週間に 1 回咬合面の制磨方行つ た。之を 5 回繰返一し，最後の調節より 2 週間後に拔 去したのであるが，結局施術に要した期間は 12 週間 であつた。

此拔去㒷牙，とそ机に附著せる一部の落槽骨及び

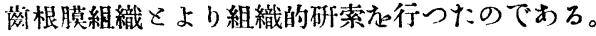

絁槽緣頂に於いては, 多くの造骨細胞に取卷かれけ

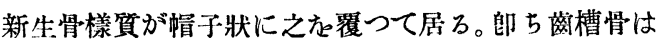

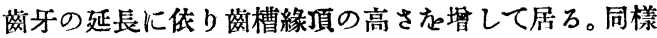
に茲牙に面した骨の表面も造骨細胞に覆はれた, 骨樣 質の薄い層の添加が認められた。根端部に於ける骨の 變化は此標本では不明である。

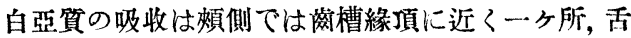
側では根端に近く三々所見られ殊に舌側に於いては 象牙筫に達するものも認められた。是等は威槽緣にお

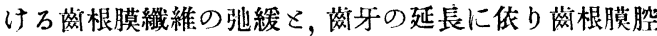
が廣くなる篇に，州牙の抵抗力が減少し㕮合に依り 落牙が傾斜し生ずるのである。前根膜の厥迫は短時閒 で然も間歇的であろなら組織の 破碎や細胞の壞死の 原因をはならない。此白亞質の吸收法拔去時には多か れ少かれ修復の狀態が認められた。殊に茼槽綵頂に近 い方の吸收部は第二:白亞筫に依り全く滿たされて居 た。根端に近いものでは一つは可なり第二白亞質に依 り滿たされて居るが, 他はまだ完全になつて居ない。 然し造白亞質細胞に覆はれた白亞質溙物質の層が認 められた。

白亞筫は一般に治瘾傾向が大でその吸收か起せる 原因の消失するや否や，治癒機轉が始まるものです ろ。然し乍ら或場合には反對に管惡の傾向芷示すこさ

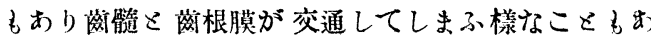
ろ。か〉る傾向は糜、强い力か用ひた場命に見られる そのである。

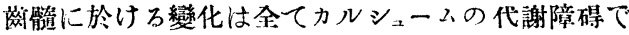
むる。これは成人に於て外傷性障碍が象牙質塯の形成 の原因であると一部の人に考へられて居万如くに此 場合にも，落牙移動が外傷性障碍としてカルシューム

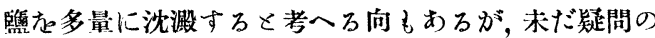
點である。

勿論この一つの標本より結論去下すことは偷早で あり，將來更に㸴究する必要があるが，强い力方用ひ て大融の延長方計つたりする場合余の經驗に依れば

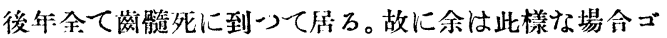
ムリングの弱い彈力か使用する。而も是等は 1 週に 2 回夜間にのみ使用する。若し犬茼の位置が良好でむつ たならその萠出餘地を譃げるに止め後は自然の萠出 力长利用寸ろのが最良である。（高橋晃次郎抄） 